\title{
Effect of Weather Conditions on Frit Fly (Oscinella frit, Diptera: Chloropidae) Activity and Infestation Levels in Spring Wheat in Central Germany
}

\author{
Nabil El-Wakeil · Christa Volkmar
}

Received: 10 April 2011 / Accepted: 20 May 2011 / Published online: 18 June 2011

(C) The Author(s) 2011. This article is published with open access at Springerlink.com

\begin{abstract}
Effects of temperature, rainfall and solar radiation on frit fly (Oscinella frit) population and infestation level were evaluated in two wheat varieties in central Germany during 2008-2010. The effect colour of water traps (blue, white and yellow) -used in population determination- on their efficiency was also evaluated. Strong correlation was found between weather parameters and trap catches $\left(\mathrm{R}^{2}\right.$ between 0.8 and 0.98$)$. Infestation percents were calculated by counting the infested plants at different growth stages 10-30. The weather conditions in 2008 and 2009 were drier, warmer and sunnier than 2010, which affected trap catches as well infestation percents. There was a positive correlation between blue trap catches and solar radiation and negative correlation with white and yellow traps. Infestation percents were higher in 2008 \& 2009 than in 2010; although trap catches were higher in 2010 than 2008 \& 2009, because weather conditions affected adult negatively ovipositon and newly larvae survival in 2010. The results indicate that weather can play a precise role in frit fly activity and its infestation levels.
\end{abstract}

Keywords Oscinella frit infestation · Wheat · Temperature $\cdot$ Rainfall $\cdot$ Solar radiation $\cdot$ Water traps

\section{Einfluss von Witterungsbedingungen auf die Aktivität der Fritfliege (Oscinella frit $\mathrm{L}$.) und den Befall an Sommerweizen}

Zusammenfassung In einem dreijährigen Parzellenversuch am Standort Halle (Saale) wurde der Einfluss von Witterungsbedingungen (Temperatur, Niederschlag und Globalstrahlung) auf die Aktivität und das Schadausmaß der Fritfliege untersucht. Zur Überwachung der Aktivität kamen Farbschalen (blau, weiß und gelb) zum Einsatz und der Infektionsgrad wurde mittels Sichtbonituren zu unterschiedlichen BBCH-Stadien ermittelt. Die Witterungsbedingungen beeinflussten die Aktivität und das Infektionsniveau. Es bestand eine positive Korrelation zwischen den Blauschalenfängen und der Globalstrahlung und die Fänge in den Weiß- und Gelbschalen zeigten einen negativen $\mathrm{Zu}-$ sammenhang. Die Schädigung der Pflanzen (\%) war 2008 und 2009 höher als 2010, offensichtlich beeinflussten die ungünstigen abiotischen Bedingungen 2010 das Befallsgeschehen negativ. Die dreijährigen Befunde zeigen, dass die Wetterbedingungen im Frühjahr zu BBCH 10-20 entscheidend sind für die Ausprägung des Schadausmaßes an Sommerweizen.

Schlüsselwörter Fritfliege $\cdot$ Temperatur · Niederschlag · Globalstrahlung $\cdot$ Wasserschalen

\section{Introduction}

Weather parameters are the dominant factors determining the distribution and abundance of most insect species. Oscinella frit, (Diptera: Chloropidae) is a stem-borer which can cause considerable damage to cereals that sown in spring. Weather parameters are dominant factors determining the distribu-

\author{
Institute of Agric. \& Nutritional Sciences, \\ Martin-Luther-University, Halle-Wittenberg, Germany \\ e-mail: nabil.el-wakeil@landw.uni-halle.de \\ N. El-Wakeil \\ Pests \& Plant Protection Dept. National \\ Research Centre, Dokki, Cairo, Egypt
}


tion and abundance of many insect species including $O$. frit. Spring wheat in is susceptible to frit fly infestation during a limited period at early growth stages in central Germany. Fluctuations in the population of a pest during the year produce concomitant variations in damage. Life cycle of frit fly is ca. 20-60 days, eggs are laid one or in groups (1-15 eggs) behind sheath of first leaf, fecundity reaches 25-30 eggs, and embryonic development lasts (4-10 days) Lindblad and Sigvald (1996). Larvae hatch (three instars) and feed by tunnelling in stems to crown near soil surface. The larvae of older instars feed on tissues of growing- points. The larvae period lasts 13-20 days (Volkmar and Wetzel 1984; Lindblad and Sigvald 1996). Tillers attacked by frit fly show the classic 'dead heart' symptoms of a yellow central leaf which can be easily pulled away from the surrounding green leaves. Frit fly maggots attack the young plants (1-4 leaves) this leads to plant loss and in severe attacks whole crops have had to be re-drilled where control measures have not been used. The maggots are able to survive in the decaying plant debris and can migrate to feed on the newly sown crop (Lindblad 1999).

The insect opportunities to exploit plants during these periods are affected by weather conditions in several ways (Kingsolver 1989). The synchronization between insect and plant phenologies varies due to weather variation. Furthermore, weather conditions during the susceptible period of the host plant directly influence infestation rates, by e.g. affecting the insect oviposition rate or mortality (Bentley and Clements 1989; El-Wakeil et al. 2009).

Coloured water traps are often used to sample flying insects. Insects are attracted visually by the colour of the traps and are then captured in the water in them. Studies have demonstrated the preferences of a variety of insect groups for particular trap colours (Finch 1992; Barker et al. 1997). Previous studies using coloured traps to collect adult frit flies have looked at colour preferences and support the use of blue traps Lindblad and Sigvald (1996).

The objectives of this work were to assess the role of some weather conditions (temperature, rainfall and solar radiation) on frit fly population in spring wheat fields, its infestation levels and the response of frit fly catches to different coloured water traps.

\section{Materials and Methods}

\section{Spring Wheat Plots}

The experiments were carried out sandy loam soil in research station (Lehr-und Versuchsstation, (LVS)) in Martin Luther University- Halle, Germany. An Egyptian wheat variety (Sakha 93) known to be drought resistant (Ibrahim et al. 2011), and high quality German variety (Triso) were chosen for these experiments, which were cultivated in the spring. The experimental area was designated as Randomized Complete Block, divided into four blocks $($ plot $=1.5 \times 3 \mathrm{~m}) ; 10$ replicates were conducted. Weather condition parameters were $\left(19^{\circ} \mathrm{C}, 0.9 \mathrm{~mm}\right.$ and $\left.1913 \mathrm{~J} / \mathrm{cm}^{2}\right)$, $\left(14.0^{\circ} \mathrm{C}, 0.9 \mathrm{~mm}\right.$ and $\left.1727 \mathrm{~J} / \mathrm{cm}^{2}\right)$ and $\left(12.0^{\circ} \mathrm{C}, 3.1 \mathrm{~mm}\right.$ and $1212 \mathrm{~J} / \mathrm{cm}^{2}$ ) for mean daily temperature, rainfall and solar global radiation, respectively (personal communication Dr. Döring) as shown in Table 1.

\section{Water Traps}

Three colour water traps (blue, white and yellow) were used to sample adult flies in spring wheat plots. The traps consisted of metallic dishes; $25 \mathrm{~cm}$ diameter and $6.5 \mathrm{~cm}$ deep fixed in the ground and were partly filled with water with a small quantity of detergent as described by Lindblad and Sigvald

Table 1 Mean of daily temperature, rainfall and solar global radiation during 2008, 2009 and 2010 in spring wheat- in LVS, Halle

\begin{tabular}{|c|c|c|c|c|c|c|c|c|c|c|c|}
\hline Dates & $\begin{array}{l}\text { Temp. } \\
{ }^{\circ} \mathrm{C}\end{array}$ & $\begin{array}{l}\text { Rainfall } \\
\mathrm{mm}\end{array}$ & $\begin{array}{l}\text { Solar rad. } \\
\mathrm{J} / \mathrm{cm}^{2}\end{array}$ & Dates & Temp. ${ }^{\circ} \mathrm{C}$ & $\begin{array}{l}\text { Rainfall } \\
\mathrm{mm}\end{array}$ & $\begin{array}{l}\text { Solar rad. } \\
\mathrm{J} / \mathrm{cm}^{2}\end{array}$ & Dates & Temp. ${ }^{\circ} \mathrm{C}$ & $\begin{array}{l}\text { Rainfall } \\
\mathrm{mm}\end{array}$ & $\begin{array}{l}\text { Solar rad. } \\
\mathrm{J} / \mathrm{cm}^{2}\end{array}$ \\
\hline 17.04 .08 & 14.7 & 0.4 & 1602 & 17.04 .09 & 10.2 & 4.8 & 594 & 22.04 .10 & 11.3 & 0.0 & 2003 \\
\hline 21.04 .08 & 9.20 & 0.0 & 1897 & 21.04 .09 & 12.1 & 0.0 & 2346 & 26.04 .10 & 15.6 & 5.2 & 973 \\
\hline 24.04 .08 & 16.3 & 0.4 & 1849 & 23.04 .09 & 8.20 & 0.4 & 750 & 29.04 .10 & 16.8 & 0.0 & 2008 \\
\hline 28.04 .08 & 20.3 & 0.9 & 2280 & 27.04 .09 & 17.3 & 0.0 & 1972 & 03.05 .10 & 12.2 & 1.2 & 678 \\
\hline 02.05 .08 & 23.4 & 7.0 & 1764 & 30.04 .09 & 15.2 & 0.0 & 1795 & 06.05 .10 & 8.50 & 12.9 & 204 \\
\hline 06.05 .08 & 17.1 & 1.1 & 2164 & 04.05 .09 & 10.3 & 0.0 & 1505 & 10.05 .10 & 10.7 & 1.5 & 598 \\
\hline 09.05 .08 & 20.5 & 0.0 & 2657 & 07.05 .09 & 15.1 & 0.0 & 1937 & 13.05 .10 & 10.3 & 0.0 & 671 \\
\hline 13.05 .08 & 23.2 & 0.0 & 2558 & 11.05 .09 & 11.5 & 4.3 & 476 & 17.05 .10 & 11.3 & 0.0 & 1872 \\
\hline 16.05 .08 & 22.2 & 0.0 & 1183 & 14.05 .09 & 12.5 & 0.0 & 2527 & 20.05 .10 & 12.9 & 0.1 & 536 \\
\hline 19.05 .08 & 20.8 & 1.8 & 1971 & 18.05 .09 & 17.7 & 0.0 & 2170 & 24.05 .10 & 13.6 & 4.2 & 1663 \\
\hline 22.05 .08 & 18.2 & 0.0 & 1610 & 21.05 .09 & 18.5 & 1.2 & 1759 & 27.05 .10 & 13.4 & 3.0 & 1044 \\
\hline 26.05 .08 & 17.9 & 0.0 & 1083 & 25.05 .09 & 18.4 & 0.0 & 2671 & 31.05 .10 & 11.8 & 12.5 & 494 \\
\hline 29.05 .08 & 22.8 & 0.0 & 2255 & 28.05 .09 & 14.0 & 0.3 & 1952 & 03.06 .10 & 12.8 & 0.0 & 3021 \\
\hline
\end{tabular}


(1996). The traps were observed two times weekly and trapped flies were counted under binocular in the laboratory.

\section{Frit Fly Infestation}

Infestation assessment was conducted at different wheat growth stages (GS) GS 10, 12, 13, 17, 19, 21, 22, 27 and 30 based on Meier (2001), ca. 50 plants/variety. All sampled plants were examined visually for symptoms of frit fly infestation (yellow or missing central leaf) during the studied years 2008, 2009 and 2010.

\section{Statistical Analyses}

Infestation percents data was arcsine square-root transformed. The difference among treatments was analyzed by Generalized Linear Model ((GLM), ANOVA-repeated measures) using Statistix 9 program (Thomas and Maurice 2008) and following with Tukey test to compare means of varieties. Significant differences were observed at $P<0.05$ for all trials.

\section{Results}

\section{Water Traps}

In general, there were significant differences $(\mathrm{P}=0.001)$ among years in trap catches. Weather condition parameters significantly affected trap catches during 3 years.

\section{A. 2008}

There were two peaks on $6^{\text {th }}$ and $13^{\text {th }}$ May 2008 (GS 17 and 21 ) in frit flies number in the water traps. On $6^{\text {th }}$ May, the caught flies were 32, 24 and 16 flies in blue, white and yellow traps, respectively, while on $13^{\text {th }}$ May, the caught flies were 29, 58 and 36 flies in blue, white and yellow traps, respectively. The blue traps caught the highest flies (32) on $6^{\text {th }}$ May, while the white traps caught the highest flies (58) on $13^{\text {th }}$ May. The numbers then declined until end of May. There were significant differences $(\mathrm{P}=0.0312)$ among total caught of frit flies, which were 128, 173 and 140 flies in different traps (blue, white and yellow), respectively (Fig. 1a). These numbers coincided with the wheat seedlings being at a suitable growth stage for oviposition and correlated with weather condition parameters (temperature, rainfall and solar global radiation $/ \mathrm{cm}^{2}$ ) (Fig. 2a-c).

\section{B. 2009}

Trap catch were recorded in two peaks on $4^{\text {th }}$ and $11^{\text {th }}$ May 2009 (GS 17 and 21). On $4^{\text {th }}$ May, the caught flies reached to 56,49 and 34 flies/trap in blue, white and yellow traps, respectively; while on $11^{\text {th }}$ May, the fly numbers reached to 18, 39 and 16 flies/ trap in blue, white and yellow traps, respectively. The highest flies were recorded in blue traps (56 flies/trap) on $4^{\text {th }}$ May, while in the white traps reached to 39 flies/trap on $11^{\text {th }}$ May. Then, those numbers declined daily until end of May (Fig. 1b). Total frit fly catches were 221, 229 and 153 flies in different traps (blue, white and yellow), respectively; which were differed significantly $(\mathrm{P}=0.0381)$ among trap colours. The peaks correlated with weather condition parameters (temperature, rainfall and solar global radiation $/ \mathrm{cm}^{2}$ ) (Fig. 2a-c), and also coincided with growth stages of wheat seedlings for oviposition.

\section{2010}

The highest trap catches in the different water traps were recorded on $10^{\text {th }}$ May 2010 (GS 17). The frit fly numbers reached to 30, 103 and 95 flies in blue, white and yellow traps, respectively. These catch numbers declined gradually until end of May. Total trap catches were significantly differed $(\mathrm{P}=0.0242)$ among trap colours, the highest numbers were recorded in white traps (398 flies) followed by yellow traps (356 flies) and lastly came blue traps (117) (Fig. 1c). The fly numbers were correlated with suitability wheat seedlings for oviposition and also with mean of solar global radiation, temperature and rainfall (Fig. 2a-c).

\section{Infestation Percents of Frit Fly}

Generally, analyses of variance of infestation percents data showed significantly differences between wheat varieties $(\mathrm{P}=0.0001)$ as well among the studied years $(\mathrm{P}=0.001)$. Season effects may be due to the different weather conditions among years.

\section{A. 2008}

Mean of infestation percentages in Sakha 93 and Triso varieties were 2.7 and $4.1 \%$ at GS 10 respectively. These percents reached to $13.1,28.5,58.5$ and $63.0 \%$ at GS 12 , 13, 17 and GS 19 in Sakha 93 variety. While in Triso variety, these percents reached to $25.3,54.0,74.8$ and $79.0 \%$ at GS 12, 13, 17 and GS 19, respectively (Fig. 3a). The analyses of data showed that there were significant differences between wheat varieties $(\mathrm{P}=0.0027)$; the infestation percents in Triso variety were higher than Sakha 93 variety. These percents were reduced to $56.7,41.2,36.7$ and $20.0 \%$ at GS 21, 22, 27 and GS 30 in Sakha 93 variety. While in Triso variety, these percents were $70.0,56.3,46.7$ and $26.7 \%$ at GS 21, 22, 27 and GS 30, respectively (Fig. 3a). 
Fig. 1 Number of frit fly catches by different colour water traps and their relation to global radiation $\left(\mathrm{J} / \mathrm{cm}^{2}\right)$ in spring wheat (a) 2008, (b) 2009 and (c) 2010
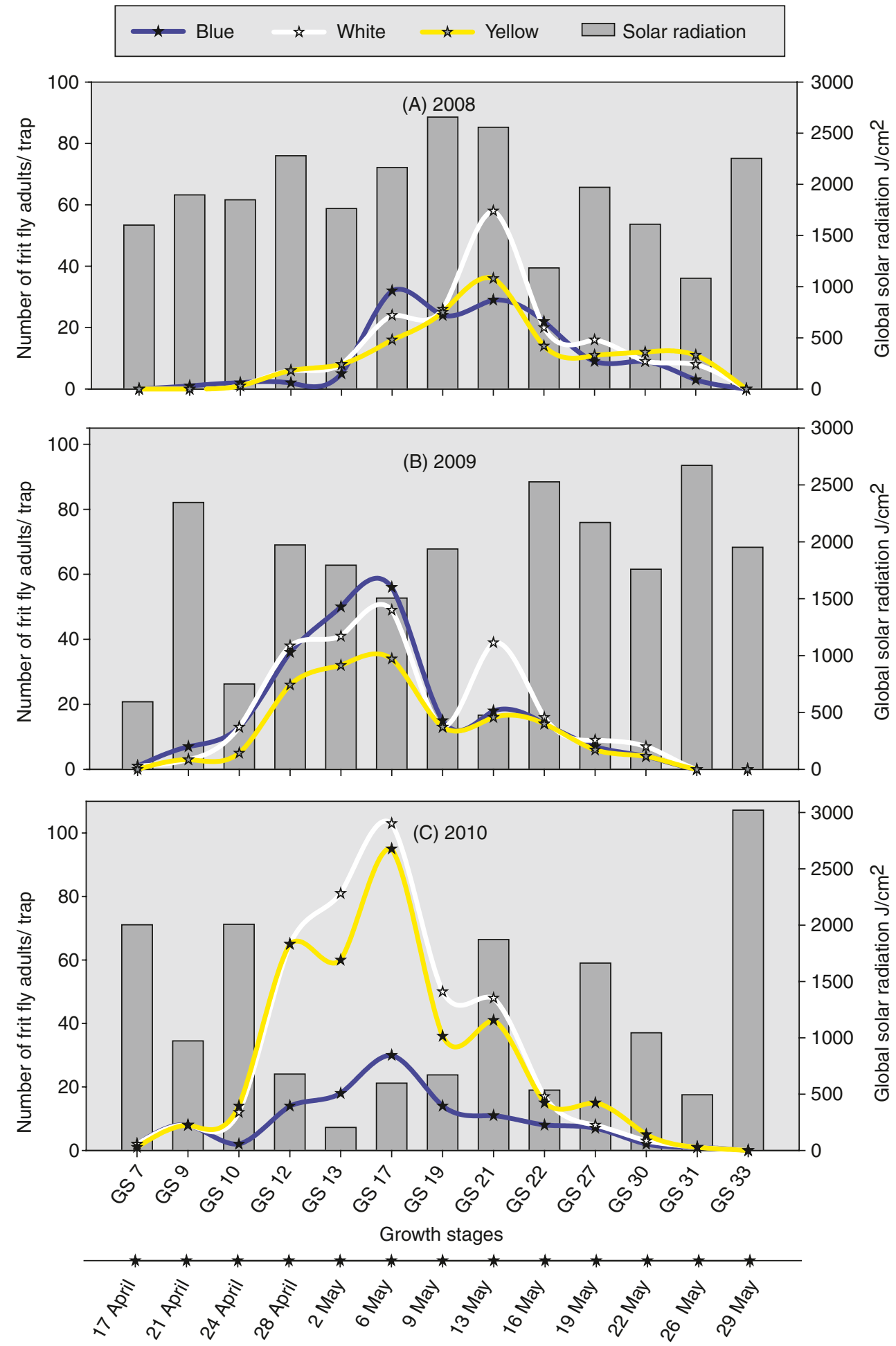

$\frac{v}{0}$
$\frac{0}{0}$
$\frac{5}{0}$
$\frac{0}{0}$
$\frac{\pi}{0}$
$\frac{\pi}{2}$
$\frac{\pi}{0}$
$\frac{0}{\pi}$
$\frac{0}{0}$
$\frac{0}{10}$

\section{B. 2009}

The analyses of data showed that there were significant differences between wheat varieties $(P=0.0032)$. Mean infestation percents in Triso and Sakha 93 varieties were 1.5 and $2.4 \%$ at GS 10, respectively. These percents reached to 10.1 , 34.0, 41.0 and 48.2\% at GS 12, 13, 17 and GS 19 in Sakha
93 variety. While in Triso variety, these percents reached to $9.8,15.5,24.1$ and $40.5 \%$ at GS $12,13,17$ and GS 19, respectively (Fig. 3b). These percents were reduced to 63.8, 52.4, 42.4 and 32.1\% at GS 21, 22, 27 and GS 30 in Sakha 93 variety. While in Triso variety, these percents were 52.3, 44.2, 36.0 and 27.3\% at GS 21, 22, 27 and GS 30, respecti- 

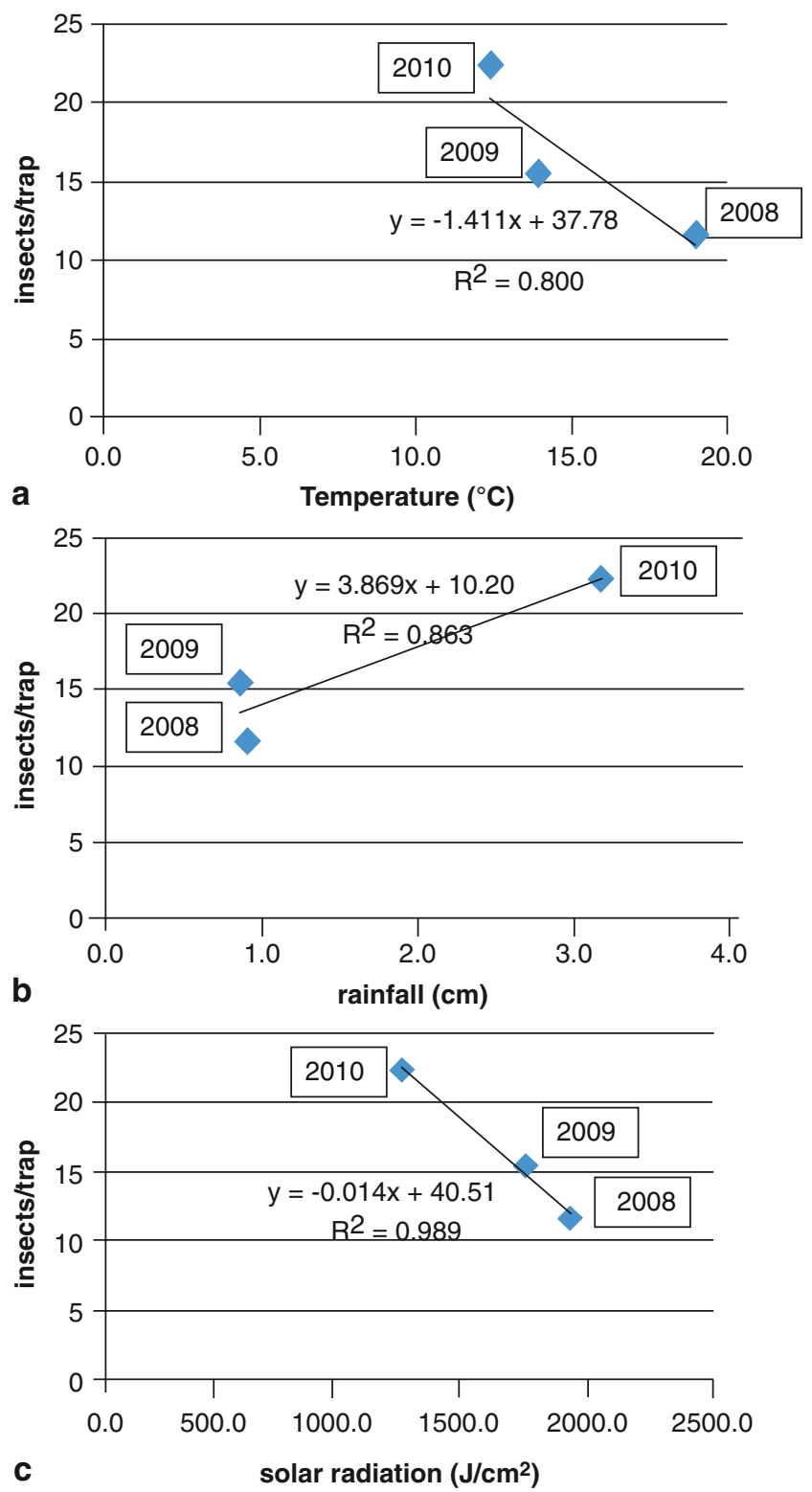

Fig. 2 Relations between weather parameters (a) Temperature, (b) rainfall \& (c) solar radiation and frit fly trap catches during 2008-2010

vely (Fig. 3b). This means that infestation percents in Sakha 93 variety were higher than Triso variety.

\section{2010}

The infestation percents were significantly differed $(\mathrm{P}=0.0038)$ between varieties; Sakha 93 had more infested tillers than Triso (Fig. 3c). Mean of infestation percentages in Triso and Sakha 93 varieties were 1.3 and $2.2 \%$ at GS 10 , respectively. These percents reached to $13.7,19.9,33.2$ and $47.9 \%$ at GS 12,13, 17 and GS 19 in Sakha 93 variety. While in Triso variety, these percents reached to $10.3,15.1$, 26.6 and $32.7 \%$ at GS $12,13,17$ and GS 19 , respectively (Fig. 3c). These percents were reduced to $43.1,41.8,35.2$ and $30.4 \%$ at GS 21, 22, 27 and GS 30 in Sakha 93 variety. While in Triso variety, these percents were 29.8, 25.9, 22.7 and $20.5 \%$ at GS 21, 22, 27 and GS 30, respectively (Fig. 3c).

\section{Discussion}

There were significant differences among trap catches in the three season-studies. The flies caught in water traps were recorded in two peaks in 2008 and 2009; while one peak was recorded in 2010. The results are consistent with previous findings by El-Wakeil et al. (2009). The high numbers were related to weather conditions as reported by Lindblad and Sigvald (1999), who stated that trap catches and infestation rates of frit fly in oats plants were related to daily weather conditions as well as plant growth stages. Similarly, Menéndez (2007) mentioned that climate changes affect biological and ecological systems of insects; as well Rygg (1966) and Barker et al. (1997) indicated that majority of flies caught in water traps were caught in early of May which had developed eggs. Trap catches were significantly differed among traps (blue, white and yellow) and also frit fly catches were correlated with solar global radiation. There was a positive correlation between blue trap catches and solar radiation and negative correlation with white and yellow traps in different studied years.

Our results show in agreement with Cuncliffe et al. (1925), that wheat seedlings were most susceptible to frit fly infestation during growth stages GS 11-13. Thereafter, the susceptibility rapidly decreased. Seedlings in GS 17 were considerably less susceptible than in earlier stages. However, we found that up to $30 \%$ of the main shoots may be infested in this growth stage if the infestation pressure is high. Hence, the risk of frit fly damage cannot be neglected until the spring wheat has reached GS 19-21. Spring wheat seedlings tended to be less infested in GS 10 than in the following stages (Fig. 3). This finding supports the hypothesis that very young plants are less attractive to the egg-laying female as confirmed by Jonasson (1977), but may also be due to a shorter exposure time.

Temperature and solar global radiation affected trap catches and infestation rates, whereas rainfall was less important. Few plants were infested during days with maximum temperatures lower than $12-13^{\circ} \mathrm{C}$ (Tab. 1 and Fig. 3). Our results are comparable with previous findings from studies of damage on autumn-sown cereals; where Riggert (1935) stated that egg-laying ceases at maximum temperatures below $15^{\circ} \mathrm{C}$ and that wind and rain normally do not affect infestation rate. Since spring wheat seedlings mainly are susceptible to infestation during GS 11-13, daily temperatures during these growth stages will highly influence the risk of frit fly infestation. The relationship between the develop- 
Fig. 3 Mean \pm SE of infestation percents of frit fly at different growth stages of two spring wheat varieties during three seasons (a) 2008, (b) 2009 and (c) 2010. Different letters indicate significant differences

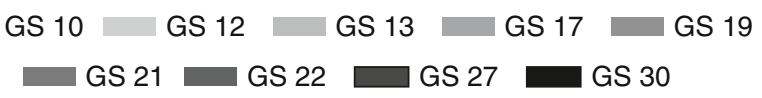

GS 30
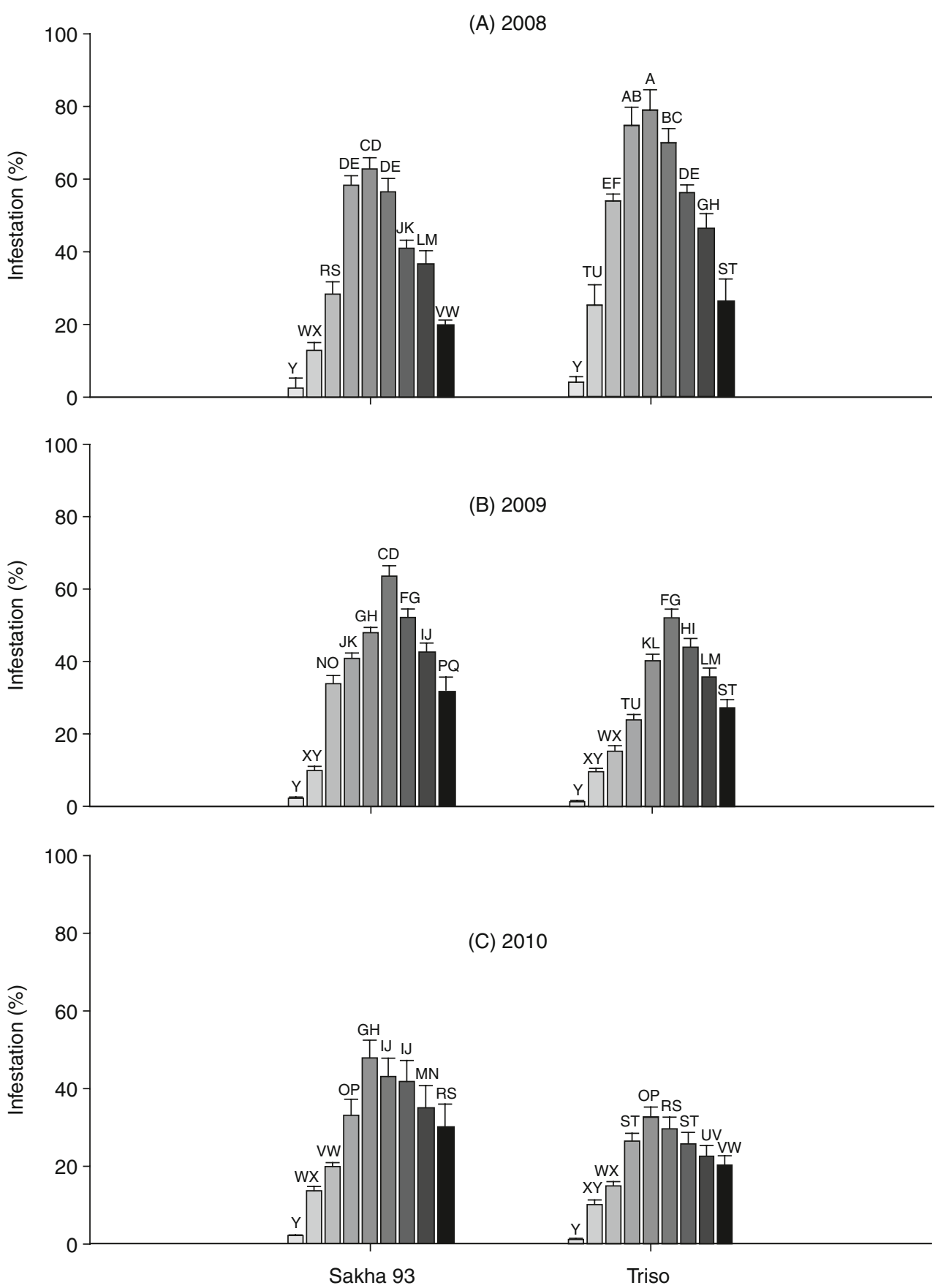

ment rate of spring wheat and temperature is approximately linear as mentioned by Saarikko and Carter (1996); Lindblad and Solbreck (1998) and the duration of these growth stages depends on weather conditions.

Triso had more infested tillers than Sakha 93 in 2008 and vice versa in 2009 and 2010 (infestation was in Sakha 93 higher than Triso variety in 2009 and 2010). This may be due to one variety grows faster than the other variety with respect to different weather conditions. Generally, infestation percents were higher in season 2008 and 2009 than 2010; this may be due to weather condition parameters which affected on frit fly activities (hibernation- frit fly emergence, egg oviposition and larval activity) as declared by Lindblad (1999). Frit fly adults has a good chance to lay their egg till GS 
13, commonly occurs in early of season as confirmed by Southwood et al. (1961) and Tolley and Niemzcyk (1988); while plants are still young. Larval activity stopped at GS 19-21 then declined till GS 31-33.

Early spring wheat will escape in most cases from frit fly infestation even if the weather is warm during the most susceptible growth stages, because the flies have not yet emerged. The time of frit fly emergence can be predicted with relatively high accuracy, although forecasting errors may arise due to e.g. choice of weather station within a region as reported by Jonasson (1977); Clements et al. (1990); Lindblad and Sigvald (1996, 1999). However, our study shows that although significant damage of seedlings in GS 17-19 is uncommon, it cannot be totally excluded. In years with high abundance of frit flies and warm weather, early-sown crops may suffer unexpected damage due to infestation in this growth stage. Hence, to explain the incidence of frit fly damage, it is necessary to consider not only the timing between insect and crop phenologies, but also the influence of weather conditions at trap catches, oviposition, larval infestation and variation in population size between years. In conclusion, there were two stages; firstly, frit fly-overwinter-emergence which affected by rainfall and solar radiation and secondly, fly infestation that affected by temperature. Climate is the dominant factor determining the distribution and abundance of most insect species.

Acknowledgements The authors are highly acknowledged and appreciated the practical comments on this manuscript by Prof. M. Saleh (National research Centre, Egypt) and Dr. M. Jallow (Okanagan-Kootenay Sterile Insect Release Program, Canada).

Open Access This article is distributed under the terms of the Creative Commons Attribution Noncommercial License which permits any noncommercial use, distribution, and reproduction in any medium, provided the original author(s) and source are credited.

\section{References}

Barker AM, Sanbrooke KJ, Aebischer NJ (1997) The water trap colour preferences of farmland sawflies. Entomol Exp Appl 85:83-86

Bentley BR, Clements RO (1989) Impact of time of sowing on pest damage to direct-drilled rass and the mode of attack by dipterous stem borers. Crop Prot 8:55-62

Clements RO, Bentley BR, Jackson CA (1990) Influence of date of sowing on frit-fly damage to newly sown Italian rye grass. Crop Prot 9:101-104

Cuncliffe N, Fryer JC, Gibson GW (1925) Studies on Oscinella frit L. The correlation between stage of growth of stem and susceptibility to infestation. Ann Appl Bio 33:516-526

El-Wakeil N, Sallam A, Volkmar C (2009) Ecological studies on frit fly Oscinella frit (L.) and its control in summer wheat. Mitt Dsch Ges Allg Angew Entomol 17:215-220

Finch S (1992) Improving the selectivity of water traps for monitoring populations of the cabbage root fly. Ann Appl Biol 120:1-7

Ibrahim ME, Abdel-Aal SM, Hussein AS, Gafar NA (2011) Technological, rheological and yield differences among Egyptian wheat varieties. J Sci Food Agric. doi: 10.1002/jsfa.425
Jonasson T (1977) Frit fly Oscinella frit oviposition on oat seedlings: ecological significance of the host plant selection. Oikos 29:104-111

Kingsolver JG (1989) Weather and the population dynamics of insects: integrating physiological and population ecology. Physiol Zool 62:314-334

Lindblad M (1999) Density and mortality of overwintering Oscinella frit and other oscinellids in Swedish grasslands. Internat J Pest Manag 45:23-28

Lindblad M, Sigvald R (1996) A degree-day model for regional prediction of first occurrence of frit flies in oats in Sweden. Crop Prot 15:559-565

Lindblad M, Sigvald R (1999) Frit fly infestation of oats in relation to growth stage and weather conditions at oviposition. Crop Prot 18:517-521

Lindblad M, Solbreck C (1998) Predicting Oscinella frit population densities from suction trap catches and weather data. J Appl Ecol $35: 871-881$

Meier U (2001) Growth stages of mono-and dicotyledonous plants, 2nd edn. Fed Biol Res Centre for Agric \& Forest, Darmstadt, p 158

Menéndez R (2007) How are insects responding to global warming? Tijdschrift voor Entomol 150:355-365

Riggert E (1935) Zur Kenntnis der Lebensgewohnheiten von Oscinella frit L. und ihrer Jugendstadien. Arbeit Physiol Angew Entomol Berlin-Dahlem 2:101-156

Rygg YD (1966) Flight of Oscinella frit L. females in relation to age and ovary development. Entomol Exp Appl 9:74-84

Saarikko RA, Carter TR (1996) Phenological development in spring cereals: response to temperature \& photoperiod under northern conditions. Euro J Agron 5:59-70

Southwood TRE, Jepson WF, Vanemoen HF (1961) Studies on the behaviour of Oscinella frit L. adults of the panicle generation. Entomol Exp Appl 4:196-210

Thomas CR, Maurice SC (2008) Statistix 9, 9 th edn. Managerial Economics McGraw-Hill/Irwin. (ISBN: 0073402818). http://www. statistix.com

Tolley MP, Niemzcyk HD (1988) Seasonal abundance, oviposition activity \& degree-day prediction of adult frit fly occurrence on turfgrass in Ohio. Environ Entomol 17:855-862

Volkmar C, Wetzel T (1984) Zur Artenfrage und zum Auftreten von Oscinella spp. In den Blütenständen wichtiger Getreidearten. Arch Phytopathol Plant Prot 20:317-324

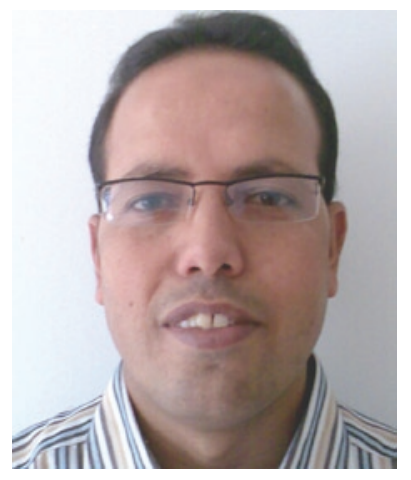

Dr. Nabil El-Wakeil was born in 1969 in Tanta, Egypt. In 1991, he completed his academic degree in Agricultural sciences in Menofyia University, Egypt with a major in Plant Protection and minors in Economic Entomology. He conducted his Master research on "Ecological studies on certain natural enemies of maize and sorghum pests" (p 212) in Cairo University, Egypt. Dr. El-Wakeil completed his doctorate in 2003 at Department of Entomology, Crop Sciences, University of Goettingen, Germany. The topic of his dissertation was "New aspects of biological control of Helicoverpa armigera in organic cotton production ( $p$ 140). $\mathrm{He}$ had started working in National Research Center (Pests and Plant Protection dept.) in Cairo, Egypt from May 2003 till June 2010. Since July 2010, Dr. Nabil El-Wakeil works as Post doc fellow in Martin Luther- Halle University. 